\title{
An Assessment of Prehistoric Sites 41CP228 and 41CP229 Camp County, Texas
}

Glenn T. Goode

Follow this and additional works at: https://scholarworks.sfasu.edu/ita

Part of the American Material Culture Commons, Archaeological Anthropology Commons, Environmental Studies Commons, Other American Studies Commons, Other Arts and Humanities Commons, Other History of Art, Architecture, and Archaeology Commons, and the United States History Commons

Tell us how this article helped you.

This Article is brought to you for free and open access by the Center for Regional Heritage Research at SFA ScholarWorks. It has been accepted for inclusion in Index of Texas Archaeology: Open Access Gray Literature from the Lone Star State by an authorized editor of SFA ScholarWorks. For more information, please contact cdsscholarworks@sfasu.edu. 


\section{An Assessment of Prehistoric Sites 41CP228 and 41CP229 Camp County, Texas}

\section{Licensing Statement}

This is a work produced for the Texas Department of Transportation (TxDOT) by the report producer. TxDOT and the report producer jointly own all rights, title, and interest in and to all intellectual property developed under TXDOT's contract with the report producer. The report may be cited and brief passages from this publication may be reproduced without permission provided that credit is given to both TxDOT and the report producer. Permission to reprint an entire chapter, section, figures or tables must be obtained in advance from either the Supervisor of the Archeological Studies Branch, Environmental Affairs Division, Texas Department of Transportation, 125 East 11th Street, Austin, Texas, 78701 or from the report producer. 


\section{An Assessment of Prehistoric Sites 41CP228 and 41CP229 Camp County, Texas}

By

Glenn T. Goode

September 1997

\section{Archeology Studies Program Cultural Resource Management Section Environmental Affairs Division Texas Department of Transportation}




\section{Table of Contents}

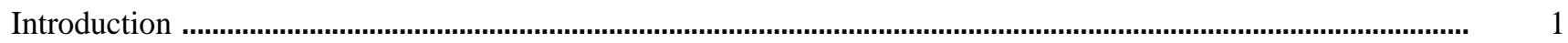

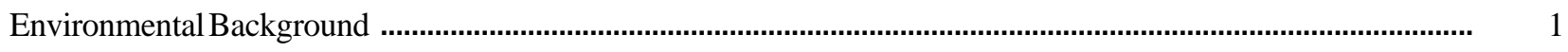

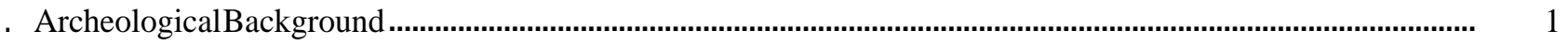

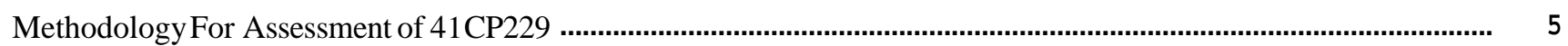

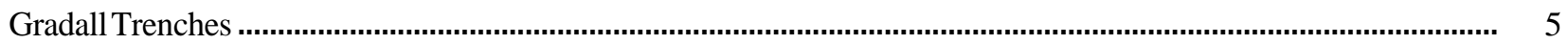

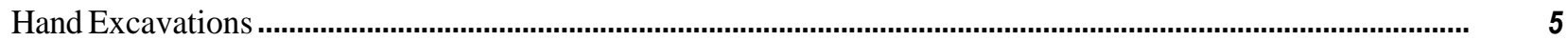

Anomalies and Possible Cultural Features ........................................................................................................ 5

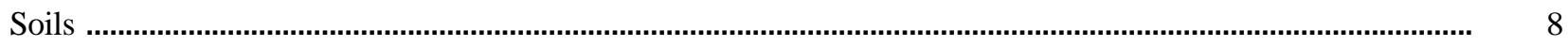

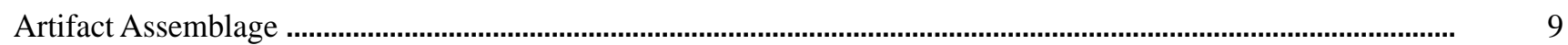

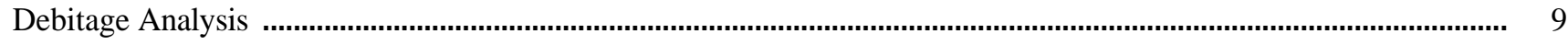

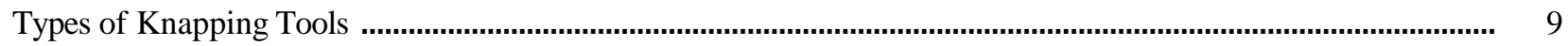

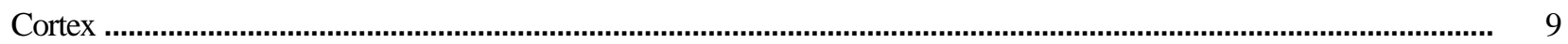

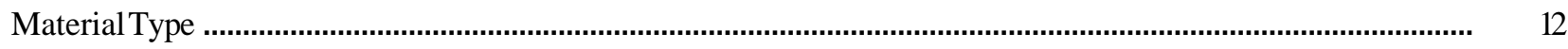

Diagnostic Artifacts. Biface Fragments. and Other Tools ............................................................................ 12

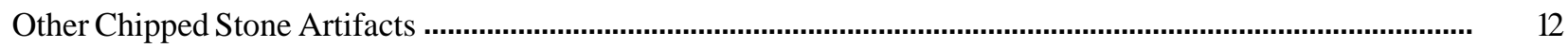

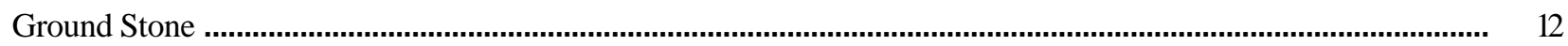

Excavations at 41CP228

Assessment and Recommendations .....................................................................................................................

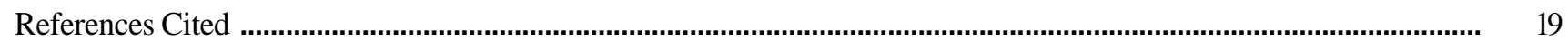




\section{List Of Figures}

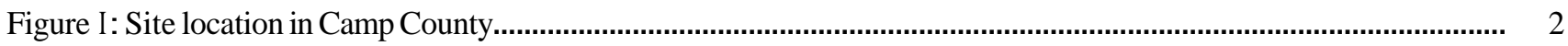

Figure 2: Site location on topographic map ................................................................................................. 3

Figure 3: Location of Gradall trenches and shovel tests at 41CP229....................................................................... 4

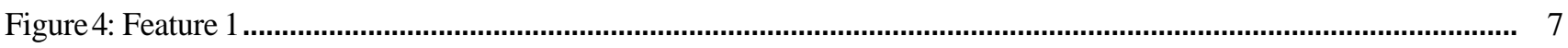

Figure 5: Selected artifactsfiom 4 1CP229........................................................................................................... 11

Figure 6: Location of Gradall trenches and shovel tests at 41 CP228 ..................................................................... 15

\section{LIST OF TABLES}

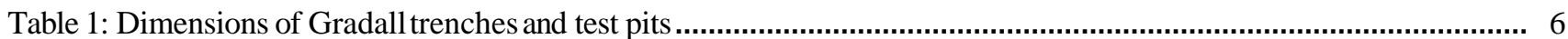

Table 2: Distribution of Lithic Debitage(flakes) at 41CP229.............................................................................. 10

Table 3: Distribution of tools fiom shovel tests at 41CP229 .............................................................................

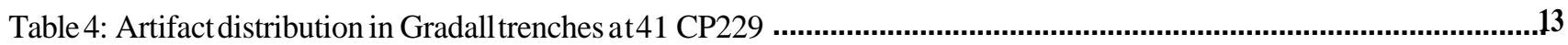

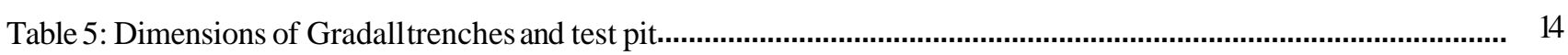




\section{INTRODUCTION}

The road along which sites $41 \mathrm{CP} 228$ and 229 occur is F.M. 1520 (Fig. 1 and Fig. 2), with the limits of improvements to it being from $0.8 \mathrm{mi}$. north of Loop 179 to 0.7 mi. north of Walkers Creek--a length of approximately 1.25 miles. This is a particularlydangerous stretch of roadway with curves at Walkers Creek and its tributary to the north. Along this stretch in recent years several people have died in automobile accidents, most recently during the course of the fieldwork in September, 1996. The proposed work will realign the roadway to eliminate the curves, and construct two new multiple box culverts.

An assessment of these prehistoric sites was conducted between September 3 and September 18, 1996, but a total of only 7 days was spent in the field. The sites were recorded in 1993, with shovel testing done at both and recommendations made for further work. From 39 shovel tests at $41 \mathrm{CP} 229$, a total of 5 artifacts was found and the site was recommended for test excavation.In an area near site 41CP228, no artifacts were found in 17 shovel tests and the site appeared to be outside the right-of-way; however, it was recommended that monitoring should be done during construction.

The purpose of the recent work was to determine if the part of site 41CP229 in the proposed right-of-way warranted formal test excavation, and if site 4 1CP228 extended into the right-of-way. This evaluation of the sites was done with a combination of Gradall scraping and hand excavation of large shovel tests. The emphasis of the work at $41 \mathrm{CP} 229$ was on finding features such as house patterns in the relatively shallow sandy deposit and underlying clay.

\section{ENVIRONMENTAL BACKGROUND}

Camp County and the surrounding region occur within the West Gulf Coastal Plain portion of the Coastal Plain Physiographic Province (Sellards, et al, 1932). The region is underlain by various formations of the Eoceneage Claiborne Group, including the Carrizo Sand, the Reklaw Formation, the Queen City Formation, and the Wilcox Group (Bureau of Economic Geology). The present project, which is not very long, appears to lie entirely upon the CarrizoSand.

The region's topography is mostly rolling to hilly, with occasional flat areas along divides and floodplains. Dominated by oak-hickory-pine forests, the Camp County region lies within, although fairly near the western margin of, the Austroriparian Biotic Province (Blair 1950), which extends eastward to the Atlantic.

This part of Texas has a humid subtropical climate characterizedby hot summers and mild winters (Carr 1967). As in most regions of the state, the greatest rainfall occurs in late spring and early fall, the mean annual amount being about 44 inches.

\section{ARCHEOLOGICAL BACKGROUND}

The cultural chronology of northeast Texas, much as the surrounding regions, is usually presented as a scheme of four periods of stages. As described by Story (1981), these are: Paleoindian (ca. 10,000 to 6000 B.C.); Archaic (ca. 6000 to 200 B.C.); Early Ceramic (ca. 200 B.C. to A.D. 800); and Late Prehistoric (ca. A.D. 800 to 1600).

Both the earlier (Clovis) and later (Dalton, San Patrice, Scottsbluff) manifestations of the Paleoindian Stage are found either in the whole of east Texas, or in the northeastern portion that includes Camp County.

The Archaic Stage is often discussed in terms of three periods (Early, Middle,Late) of approximately 2000 years each. Some of the major temporal indicators of the Archaic are known by type names such as Johnson, Calf Creek, Wells, Morrill, Trinity, Yarbrough, Gary, and Kent. The Gary and Kent types, at least, persist into the Early Ceramic period which is better recognized by ceramics such as Williams Plain, and types of the Marksville and Troyville cultures. Arrowpoint types of the period, such as Friley and Colbert, have expanding stems.

Around A.D. 800, the Formative Caddoan period was developing, and was then followed by the Early, Middle, Late, and Historic Caddoan periods. The Coles Creek culture, though weakly represented this far west, perhaps also made its appearance in northeastern Texas in the 9th century at sites on down the Big Cypress and elsewhere.

Previous work in the vicinity includes TxDOT's excavation of the Tankersley Creek Site (Young 1981) across the Big Cypress in Titus County. A good variety of Archaic, as well as Early Ceramic and Caddoan materials, was recovered from this site.

At nearby Lake Bob Sandlin on the Big Cypress, minor excavationsconducted in the 1970s produced mostly Late Archaic and Caddoan materials (T.K. Perttula, personal communication 1996). 


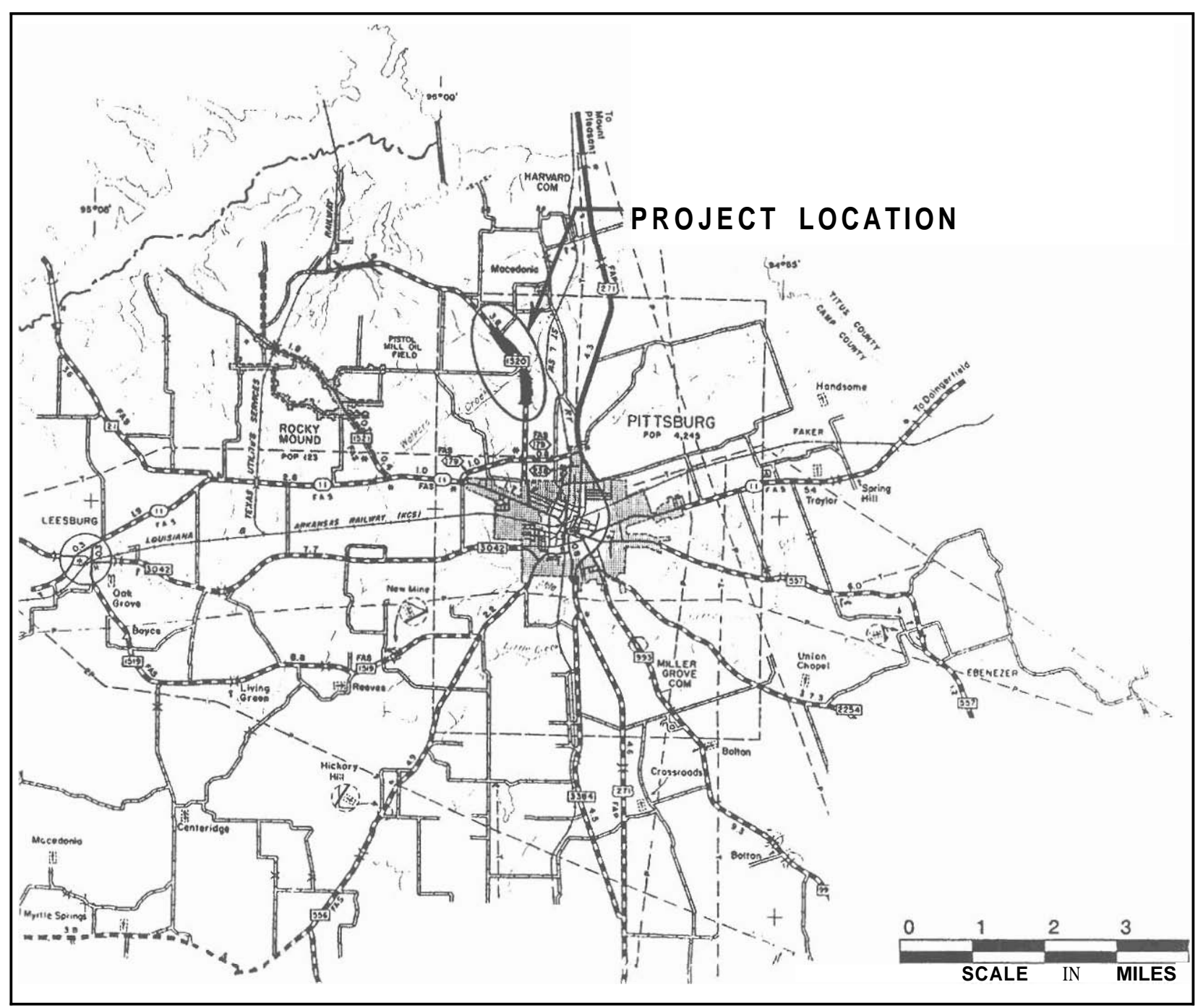

Figure 1: Site location in Camp County. 
This Page Redacted Per THC Policy 


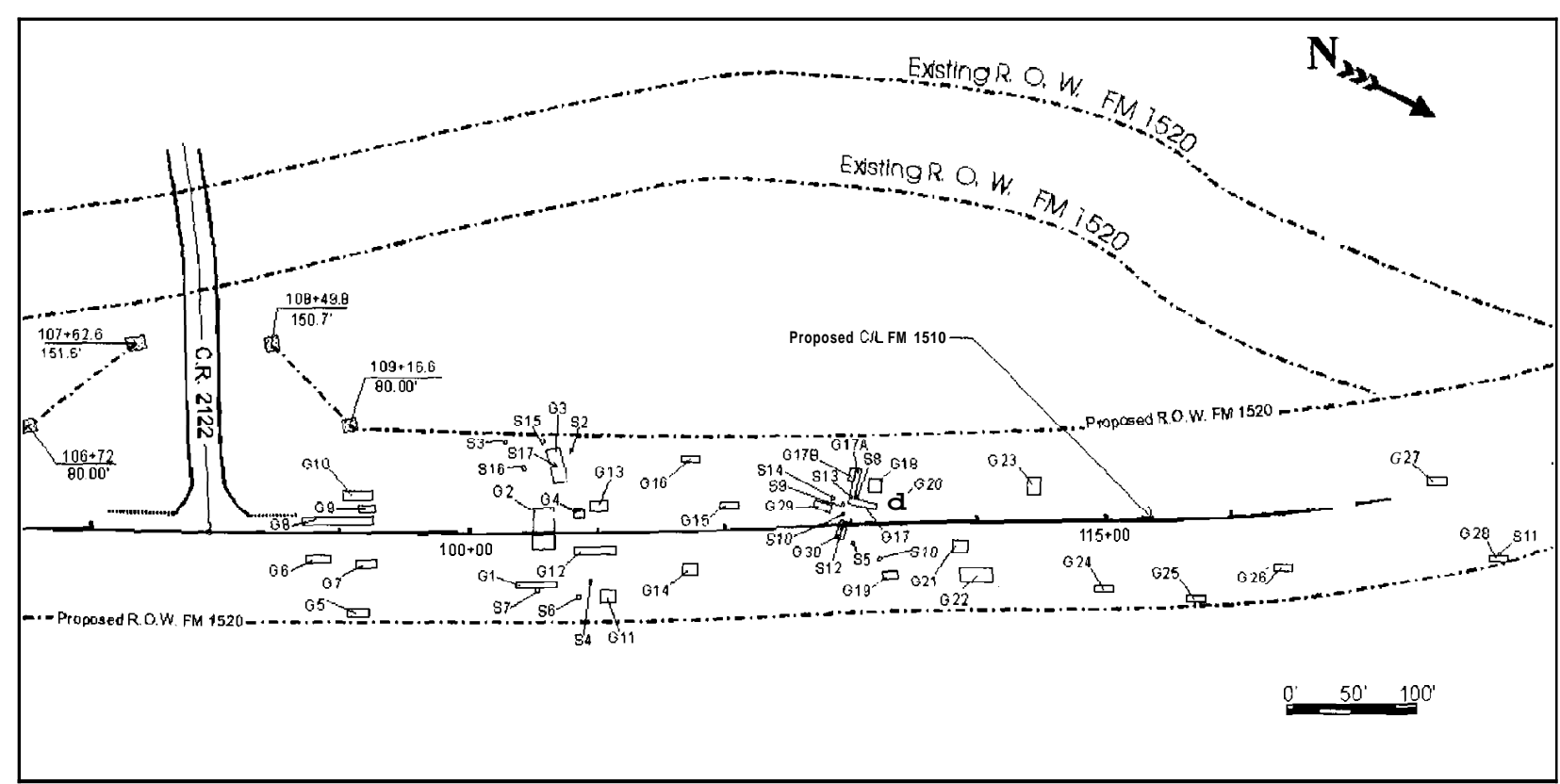

Figure 3: Location of G radall trenches and shovel tests at 41CP229. 


\section{Methodology For Assessment of 41CP229}

Because site 4 1CP229will be bisected by the proposed right-of-way of $160 \mathrm{ft}$. width, considerably more work was done at this location than at site 4 1CP228, which is outside the right-of-way. This work (Fig. 3) amounted to a total of 30 Gradall scrapes and trenches of various sizes, and 17 shovel tests, also of variable size (Table 1). The portion of site $41 \mathrm{CP} 229$ within the proposed right-of-way is within a hay meadow that has been farmed for many years. Though the hay had been recently mown and baled, there remained a cover sufficiently dense to obscure most of the ground surface. Therefore, no effort was made to find surficialconcentrations of cultural material for the purpose of placing excavations.

The rationale behind the placement of excavations was an effort to sample reasonably well the various areas of the site, such as the terrace margin, slope, and ridgetop. Several shovel tests were placed in what were judged to be likely places to find prehistoric materials, while others were placed within or adjacent to gradall scrapes following the finding of anomalies. The hand excavations, called shovel tests, were done in a more-or-less standard fashion, using the usual equipment. All of the matrix was screened through $1 / 4$ in. hardware cloth, with the return placed in labeled paper bags. Level floors were shovel shaved or troweled in an effort to find features.

\section{Gradall TRENCHES}

The proposed route for the relocation of FM 1520 will cut a swath through site 41CP229 that is approximately 800 $\mathrm{ft}$. long and $160 \mathrm{ft}$. wide (Fig. 3). For an area of this size, it was thought best to use a Gradall to quickly reveal the site's stratigraphy and contents. Although a relatively large number of Gradall trenches (GT) and scrapes was dug, the area exposed was only a fraction of the site area within the right-of-way. The area opened, though, is considered to be a representative sample of the site and sufficientfor making predictionsand recommendations.

There were three areas in which Gradall trenches and scrapes were concentrated (see Figure 3), one on the slope between the floodplain and the terrace margin ( 6 trenches between CenterlineStation (CS) 108 and 110), one on the flatter part of the terrace north of its margin (7 trenches between CS 110 and CS 111), and another between CS 112 and 114 . The remainder of the 30 Gradalltrenches were more widely scattered up the gentle rise to the apex of the low ridge dividing Walkers Creek and its tributary to the north. The trenches ranged from $2 \mathrm{~m}$ to $16 \mathrm{~m}$ in length, and from $1.8 \mathrm{~m}$ to $9.1 \mathrm{~m}$ in width. A majority of the trenches were between 4 and $5 \mathrm{~m}$ long, with 4 being longer than 10 $\mathrm{m}$ and 4 shorter than $4 \mathrm{~m}$. As a whole, this site was quite shallow and only one trench was more than a meter deep.

\section{HAND EXCAVATIONS}

Inasmuch as the part of site 41CP229 to be impacted by road construction is quite large, as previously noted, a relatively large number of hand excavations was also needed to get a good picture of the site's contents. Because this assessment of sites 41 CP228 and 229 was not approached as a full-scale test excavation, the hand excavations are called shovel tests instead of test pits. There were 17 of them (Fig. 3) and they were concentrated in two areas: along the terrace margin, and in the vicinity of Gradall Trench 17 where an anthropogenic (but recent) feature was uncovered. Only one shovel test was dug north of thisarea, beside GT 28 at CS 118.

Although these excavations were not called test pits, they nevertheless were treated much the same, being for the most part rather precisely dug squares ranging in size from 50 X $50 \mathrm{~cm}$ to $1 \mathrm{X} 1 \mathrm{~m}$ (Table 1). Excavation increments were $10 \mathrm{~cm}$ and leveled floors often were cleaned and checked for features.

\section{Anomalies and Possible Cultural FEATURES}

Close monitoring of the Gradallexcavations was also done in an effort to find features, and several anomalies or disturbances were uncovered, most of which could be easily attributed to 20th century activity and bioturbation. Of the anomalies, two were possibly prehistoric, but they could not be linked to any other features or cultural material. One of these is an irregular pit $(90 \times 225 \mathrm{~cm})$, labeled Feature 1 (Fig. 4), that was dug into the clay substrate. It was found by Gradall stripping, at a depth of $20-25 \mathrm{~cm}$ below ground surface in Gradall Trench 3 . Feature $1 \mathrm{had}$ an average depth of about $30 \mathrm{~cm}$, though it is likely that its upper portion was removed by the Gradall.It contained fairly discrete areas of darker or lighter sandy matrix, and considerable mixing or mottling of clay, charcoal, ironstone pebbles, and rodent trails. Only two small flakes were found in the screened matrix. Since Feature 1 clearly was not a trash pit, and contained widespread charcoal, it may have been an aboriginal foodpreparation pit.

The other possible prehistoric feature resembled a posthole ( $13 \mathrm{~cm}$ in diameter), but only a $10 \mathrm{~cm}$ vertical section of it remained and it did not reach the clay 
Table 1: Dimensions of Gradall trenches and test pits.

\begin{tabular}{|c|c|c|c|c|}
\hline \multicolumn{5}{|c|}{ SITE $\# 41 \mathrm{CP} 229$} \\
\hline$P \| T *$ & LENGTH & WIOTH & DEPTH & REMARKS \\
\hline GI & $11.6 \mathrm{~m}$ & $1.8 \mathrm{~m}$ & $0.9 \mathrm{~m}$ & \\
\hline 62 & $4.6 \mathrm{~m}$ & $9.1 \mathrm{~m}$ & $0.5 \mathrm{~m}$ & \\
\hline 63 & $4.3 \mathrm{~m}$ & $7.6 \mathrm{~m}$ & $0.5 \mathrm{~m}$ & N. corner elev. $=349.52^{\prime}$ lexisting grade \\
\hline 64 & $3.7 \mathrm{~m}$ & $3.0 \mathrm{~m}$ & $0.3 \mathrm{~m}$ & \\
\hline G5 & $4.6 \mathrm{~m}$ & $1.8 \mathrm{~m}$ & $0.6 \mathrm{~m}$ & \\
\hline 66 & $5.2 \mathrm{~m}$ & $1.8 \mathrm{~m}$ & $0.9 \mathrm{~m}$ & \\
\hline 67 & $4.9 \mathrm{~m}$ & $1.8 \mathrm{~m}$ & $0.3 \mathrm{~m}$ & \\
\hline 68 & $15.8 \mathrm{~m}$ & $1.8 \mathrm{~m}$ & $1.1 \mathrm{~m}$ & \\
\hline 69 & $4.3 \mathrm{~m}$ & $1.8 \mathrm{~m}$ & $0.3 \mathrm{~m} 2$ & \\
\hline GIO & $4.9 \mathrm{~m}$ & $1.8 \mathrm{~m}$ & $0.6 \mathrm{~m}$ & \\
\hline Gा1 & $4.6 \mathrm{~m}$ & $3.4 \mathrm{~m}$ & $0.9 \mathrm{~m}$ & \\
\hline G12 & $12.2 \mathrm{~m}$ & $1.8 \mathrm{~m}$ & $0.6 \mathrm{~m}$ & \\
\hline Q13 & $4.6 \mathrm{~m}$ & $3.7 \mathrm{~m}$ & $0.3 \mathrm{~m}$ & \\
\hline 614 & $4.6 \mathrm{~m}$ & $1.8 \mathrm{~m}$ & $0.3 \mathrm{~m}$ & \\
\hline G15 & $4.6 \mathrm{~m}$ & $1.8 \mathrm{~m}$ & $0.6 \mathrm{~m}$ & \\
\hline G16 & $4.6 \mathrm{~m}$ & $1.8 \mathrm{~m}$ & $0.6 \mathrm{~m}$ & \\
\hline GI7 & $8.8 \mathrm{~m}$ & $1.8 \mathrm{~m}$ & $0.9 \mathrm{~m}$ & SW corner elev. $=352.74^{\circ}$ (ex Isting grade) \\
\hline GI7A & $1.8 \mathrm{~m}$ & $9.1 \mathrm{~m}$ & $0.9 \mathrm{~m}$ & \\
\hline GI $7 B$ & $3.7 \mathrm{~m}$ & $4.3 \mathrm{~m}$ & $0.9 \mathrm{~m}$ & \\
\hline 618 & $4.6 \mathrm{~m}$ & $5.2 \mathrm{~m}$ & $0.6 \mathrm{~m}$ & \\
\hline 619 & 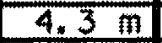 & $1.8 \mathrm{~m}$ & $0.8 \mathrm{~m}$ & \\
\hline 020 & $4.9 \mathrm{~m}$ & $3.4 \mathrm{~m}$ & $0.5 \mathrm{~m}$ & \\
\hline G21 & $4.6 \mathrm{~m}$ & $3.7 \mathrm{~m}$ & $0.6 \mathrm{~m}$ & \\
\hline G22 & $10.0 \mathrm{~m}$ & $5.5 \mathrm{~m}$ & $0.6 \mathrm{~m}$ & \\
\hline $\mathrm{G} 23$ & $4.6 \mathrm{~m}$ & $5.5 \mathrm{~m}$ & $0.5 \mathrm{~m}$ & \\
\hline $\mathrm{G} 24$ & $4.6 \mathrm{~m}$ & $1.8 \mathrm{~m}$ & $0.6 \mathrm{~m}$ & \\
\hline G25 & $4.9 \mathrm{~m}$ & $1.8 \mathrm{~m}$ & $0.5 \mathrm{~m}$ & \\
\hline 626 & $4.9 \mathrm{~m}$ & $1.8 \mathrm{~m}$ & $0.3 \mathrm{~m}$ & \\
\hline 627 & $4.6 \mathrm{~m}$ & $1.8 \mathrm{~m}$ & $0.5 \mathrm{~m}$ & \\
\hline 628 & $4.6 \mathrm{~m}$ & $1.8 \mathrm{~m}$ & $0.6 \mathrm{~m}$ & \\
\hline 629 & $4.6 \mathrm{~m}$ & $1.8 \mathrm{~m}$ & $0.6 \mathrm{~m}$ & \\
\hline G30 & $1.8 \mathrm{~m}$ & $3.7 \mathrm{~m}$ & $0.6 \mathrm{~m}$ & \\
\hline 51 & $0.5 \mathrm{~m}$ & $0.5 \mathrm{~m}$ & $0.5 \mathrm{~m}$ & \\
\hline 52 & $1.0 \mathrm{~m}$ & $1.0 \mathrm{~m}$ & $0.3 \mathrm{~m}$ & \\
\hline 53 & $0.5 \mathrm{~m}$ & $0.5 \mathrm{~m}$ & $0.3 \mathrm{~m}$ & \\
\hline$\$ 4$ & $0.8 \mathrm{~m}$ & $0.8 \mathrm{~m}$ & $0.9 \mathrm{~m}$ & \\
\hline 55 & $0.5 \mathrm{~m}$ & $0.5 \mathrm{~m}$ & $0.5 \mathrm{~m}$ & \\
\hline 56 & $1.0 \mathrm{~m}$ & $1.0 \mathrm{~m}$ & $0.9 \mathrm{~m}$ & \\
\hline 57 & $0.5 \mathrm{~m}$ & $1.0 \mathrm{~m}$ & $0.9 \mathrm{~m}$ & \\
\hline 58 & $0.75 \mathrm{~m}$ & $0.75 \mathrm{~m}$ & $0.7 \mathrm{~m}$ & \\
\hline 59 & $0.5 \mathrm{~m}$ & $0.5 \mathrm{~m}$ & $0.6 \mathrm{~m}$ & \\
\hline 510 & $0.5 \mathrm{~m}$ & $0.5 \mathrm{~m}$ & $0.6 \mathrm{~m}$ & \\
\hline SII & $0.5 \mathrm{~m}$ & $0.5 \mathrm{~m}$ & $0.5 \mathrm{~m}$ & \\
\hline 512 & $0.5 \mathrm{~m}$ & $0.5 \mathrm{~m}$ & $0.5 \mathrm{~m}$ & \\
\hline 513 & $0.75 \mathrm{~m}$ & $0.75 \mathrm{~m}$ & $0.3 \mathrm{~m}$ & \\
\hline SIA & $0.5 \mathrm{~m}$ & $0.5 \mathrm{~m}$ & $0.5 \mathrm{~m}$ & \\
\hline 515 & $1.0 \mathrm{~m}$ & $1.0 \mathrm{~m}$ & $0.2 \mathrm{~m}$ & \\
\hline 516 & $1.0 \mathrm{~m}$ & $1.0 \mathrm{~m}$ & $0.4 \mathrm{~m}$ & \\
\hline 517 & $1.0 \mathrm{~m}$ & $0.6 \mathrm{~m}$ & $0.3 \mathrm{~m}$ & \\
\hline & & & & \\
\hline
\end{tabular}


1- Gray-brown loamy sand mottled with yellow-brown to orange clay bits, small hematite pieces and olive-brown stone.

2 - Light gray to yellowish-brown loamy sand mottled with yellowbrown to orange clay bits, small hematite pieces and olive-brown stone.

3 - Pale brown to light yellow-brown sandy clay loam mottled with yellow-brown to oarnge clay bits, small hematite pieces and olivebrown stone.

4 - Dark gray-brown loamy sand with charcoal flakes, plus charcoal and other organic staining, mottled the same as the above 1,2 and 3 .
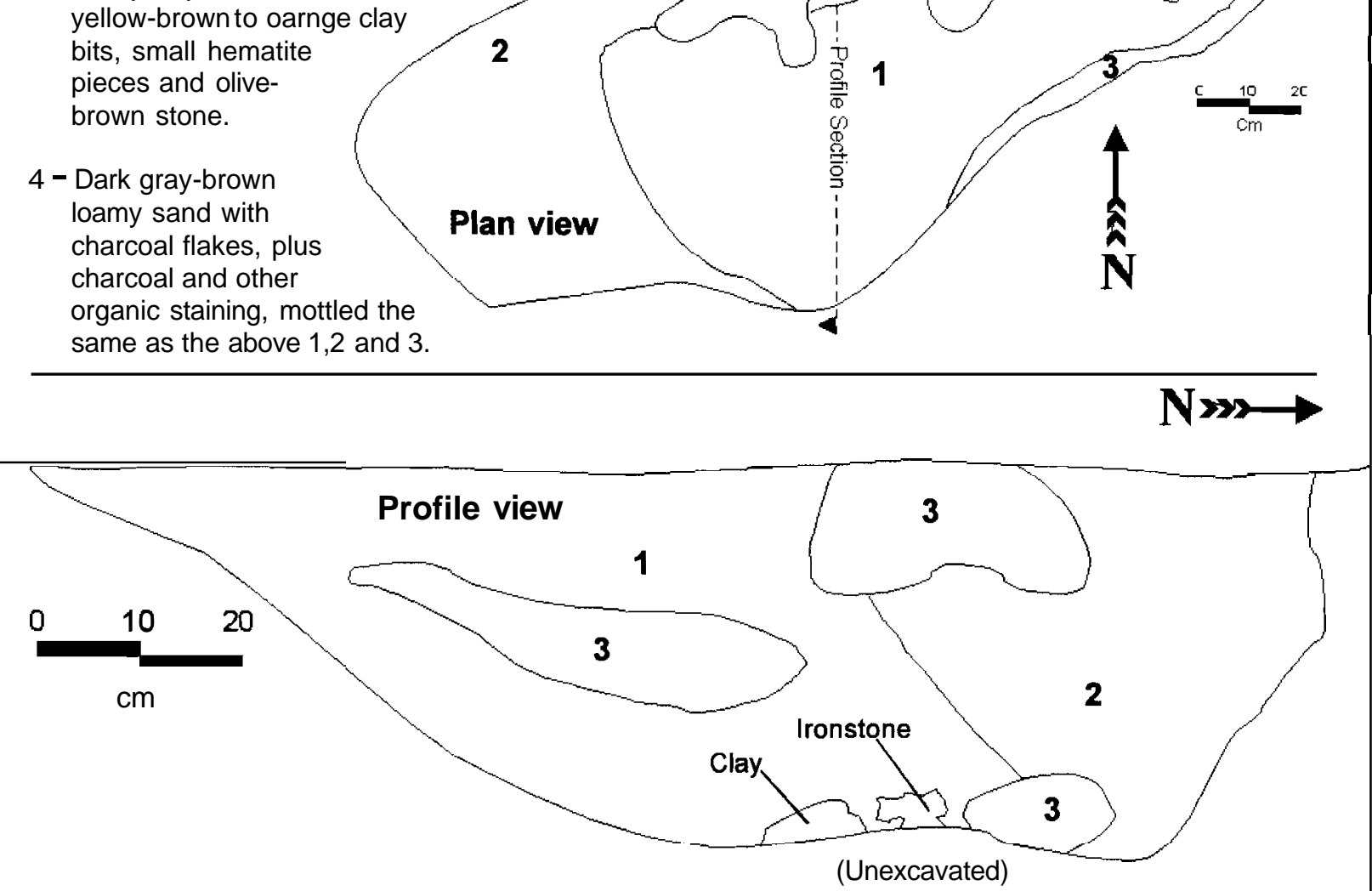

1 - Medium gray-brown sandy loam with orange mottle.

(Unexcavated)

2 - Light gray-brown sandy loam with slight orange mottle.

3 - Medium yellowish-brown sandy loam with much orange mottle.

Figure 4: Feature 1. 
substrate. After a fairly large area had been stripped, this anomaly still stood alone, so it seems more likely to have been a recent than a prehistoric disturbance.

Among the anomalies was an anthropogenic feature that at first could not be proven to be prehistoric or recent, though it was suspected to be the latter. In Gradall Trench 17 , it occurred as a thin $(5-10 \mathrm{~cm})$ lens of dark gray sandy loam, containing charcoal flecks, and being 35 to $45 \mathrm{~cm}$ below the ground surface. Expanded excavation around GT 17 demonstrated the 20th century affiliation of this feature, or disturbance. It appears to be a recent surface $(0 / \mathrm{A}$ horizon) where brush apparently was piled and burned. The area was then deep plowed and a large terrace was constructed mostly of sand stripped from nearby parts of the field. The terrace lies upon the burned area, thus preserving it under 20 to $35 \mathrm{~cm}$ of sandy matrix.

It is possible, of course, that cultural features were missed, given the comparatively minor amount of excavation within a large area. However, the sparse artifactural recovery, coupled with a failure to identify more than one cultural feature from numerous excavations, reduces the likelihood that significant features were missed.

\section{SoIls}

The excavationsat 41CP229 exposed a relatively shallow mantle of sand over most of the terrace (or bench) and upper slope that contains cultural material. In this location, high above Walkers Creek, the sandy deposit is of colluvial and aeolian origin. For the most part, the sandy deposit is about $30 \mathrm{~cm}$ in thickness, but in places it is thinner or thicker due to terracing of the field. Only in one small area, along the east right-of-way between CS 110 and 111, was the sandy deposit greater, being up to $90 \mathrm{~cm}$ in thickness. Everywhere the sandy mantle was underlain by sandy clay, of varying colors, and, below the terrace margin, by red clay and massive deposits of ferruginous sandstone which had previously served as a gravel source.

The Bowie fine sandy loam is the major soil of the project area, with the Luka fine sandy loam occurring along the floodplain of Walkers Creek (Soil Survey of Camp County). 


\section{Artifact Assemblage}

With the exception of two sherds of prehistoric ceramics, the artifacts recovered fiom 4 1CP229are made of stone. The majority of these are chipped-stone debitage and tools from siliceous stones such as flint and quartzite, with a few ground stone tools completing the sample. Typical of the region, the sample of chipped-stone debitage is composed predominately of small flakes. The ratio of tools and manufacture failures to debitage seems to be on the low side, but this may not be the case in the richer (more dart points) part of the site, which reportedly is $100 \mathrm{~m}$ or more to the east.

The total of flakes and fiagments collected from the excavations is 188 specimens(Table 2). All but three of these are from the 17 shovel tests; two others are from Feature 1 and another is fiom GT 1. A few additional flakes and one small unfinished biface were collected from the area of GT 1-4, after the holes had been filled and the backdirt washed by rains. These specimens are housed in the Atlanta District Office where they can be used as a comparative collection.

While most of the site produced extremely low numbers of artifacts fiom a shallow sandy deposit, one relatively small area along the terrace margin had a deeper deposit(approx. $90 \mathrm{~cm}$ ) as well as a higher average artifact count per level. Gradall Trench I and ST 1,4,6, \& 7 were placed in this area.

\section{DEBITAGE ANALYSIS}

The lithic debitage has been analyzed briefly to get a general understanding of stone tool manufacture at 41CP229. In this analysis, several of the more meaningful criteria were considered, but others that have sometimes been useful were not thought appropriate for this small sample. The criteria that were used are: (1) Type of K nappingTool,(2)Cortex, (3) Material Type, a nd4) Size.

To identify some of the knapping tools used at the site, the following variables were employed: Hard Hammer, Soft Hammer, Undetermined Method, and Fragment. To learn about material sources, stages of reduction and where they were performed, the variable Cortex was used, but only its presence or absence on a given specimen was recorded. Identifying MaterialType is important for assessing sources of raw material, with implications for such issues as trade and mobility. The Size of raw material bears on such problems as distance to raw material sources, reduction stages, and the kinds of tools being made.

Often, all of these variables are interrelated and the most complete picture of tool making comes from considering them together. In the case of site 4 1CP229 the debitage is dominated by flakes from final stage reduction and rejuvenation of mostly small bifaces made of local materials.

\section{TYPES OF KNAPPING TOOLS}

The kinds of knapping tools that could be identified from the debitage are the standard percussors, but the debitage of other standard kinds such as pressure tools was either missing or not obvious. Of the total of 188 flakes, 97 specimens, or 52 percent, retained the platform necessary for identification. Of these, the great majority, or 81 specimens (84 percent), had features typical of soft hammer percussion. Only 7 specimens ( 7 percent) had features usually seen on hard hammer flakes, with the balance of 9 specimens ( 9 percent) lacking definitive characterisitics (Undetermined Method).

Provided that this interpretation of the debitage is reasonably accurate, a preponderance of the flintknapping done within the project area was done with small soft hammers, or billets. The small size and generally cortex-free condition of the flakes further suggests that the work was mostly final stage manufacture of bifaces, or resharpening of them.

In making claims about the kinds of knapping tools used at a site, it must be recognized that an error factor of 10 percent or more can be expected. Regarding other reduction methods such as pressure and hammer/anvil, the former often was used as much as percussion (most of the tiny flake fragments pass through the screen), while the latter may have been used somewhere on the site.

\section{Cortex}

Of thetotal of 188 flakes and fragments, only 28 , or 15 percent, had cortex. In the Hard Hammer category, 3 of 7 specimens had cortex, and in the Undetermined Method category 3 of 9 specimenshad cortex. In comparison, only 17 of 81 (21 percent) Soft Hammer flakes had cortex, but the former categories are so small that they may not be statistically meaningful.However, these figures do follow a widespread trend in which Soft Hammer flakes have less cortex.

The relatively low percentage of cortex in this sample suggests that little primary reduction was done in this part of the site, and that there was probably not a major raw material source of any kind nearby. 
10 Archeological Assessment of Prehistoric Sites...

Table 2: Distribution of Lithic Debitage (flakes) at 41CP229.

\begin{tabular}{|c|c|c|c|c|c|c|c|}
\hline DePrH & $\begin{array}{c}\mathrm{ST}-1 \\
(50 \times 50)\end{array}$ & $\begin{array}{c}5 T-2 \\
(75 \times 75)\end{array}$ & $\begin{array}{c}5 T-3 \\
(50 \times 50)\end{array}$ & $\begin{array}{c}S T-4 \\
(70 \times 70)\end{array}$ & $\begin{array}{c}\mathrm{ST} \cdot 5 \\
(50 \times 50)\end{array}$ & $\begin{array}{c}\$ T-6 \\
(\ln \times \ln )\end{array}$ & $\begin{array}{c}\mathrm{ST} \cdot \mathrm{T} \\
(\$ 0 \mathrm{x} I \mathrm{I})\end{array}$ \\
\hline $0.10 \mathrm{~cm}$ & $s$ & 1 & 2 & 5 & 1 & 8 & 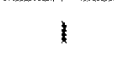 \\
\hline $10-20 \mathrm{~cm}$ & 3 & & 1 & 4 & 1 & 14 & 3 \\
\hline $20.30 \mathrm{~km}$ & 4 & & 1 & 14 & 1 & 12 & 1 \\
\hline $30-40 \mathrm{can}$ & 2 & & & 10 & 0 & 9 & 0 \\
\hline $40.50 \mathrm{~cm}$ & 0 & & & 7 & & 1 & $\mathfrak{3}$ \\
\hline $50.60 \mathrm{~cm}$ & & & & 5 & & 5 & $s$ \\
\hline $60-70 \mathrm{~cm}$ & & & & 11 & & 7 & 3 \\
\hline $70-80 \mathrm{~cm}$ & & & & 6 & & 3 & 1 \\
\hline $80.90 \mathrm{~cm}$ & & & & 0 & & 0 & 1 \\
\hline$y=163$ & 14 & 1 & 4 & 62 & 3 & 59 & 20 \\
\hline
\end{tabular}

\begin{tabular}{|c|c|c|c|c|c|c|c|}
\hline DEPTH & $\begin{array}{c}51-8 \\
(75 \times 75)\end{array}$ & $\begin{array}{c}57+0 \\
(50 \times 50)\end{array}$ & $\begin{array}{c}S T+10 \\
(50 \times 50)\end{array}$ & $\begin{array}{c}S 1-11 \\
(50 \times 50)\end{array}$ & $\begin{array}{c}S T-12 \\
(50 \times 50)\end{array}$ & $\begin{array}{c}\$ T-13 \\
(75 \times 75)\end{array}$ & $\begin{array}{c}S T+14 \\
(50 \times 50)\end{array}$ \\
\hline $0.10 \mathrm{~cm}$ & 0 & 0 & 1 & 0 & 2 & & 0 \\
\hline $10-20 \mathrm{~cm}$ & 0 & 1 & 0 & & 0 & & \\
\hline $20.30 \mathrm{~cm}$ & 0 & 1 & 2 & & 1 & & \\
\hline $30-40 \mathrm{~cm}$ & 2 & 0 & $\theta$ & & 0 & 0 & \\
\hline $40.50 \mathrm{~cm}$ & 0 & & & & & & \\
\hline $50+60 \mathrm{~cm}$ & 1 & & & & & & \\
\hline \multicolumn{8}{|l|}{$60-7 \mathrm{~cm}$} \\
\hline $9 \cdots$ & 3 & 2 & 3 & 0 & 3 & 0 & 0 \\
\hline
\end{tabular}

\begin{tabular}{|c|c|c|c|}
\hline DEPTH & $\begin{array}{c}S T-15 \\
(1 \mathrm{~m} \times \operatorname{lm})\end{array}$ & $\begin{array}{c}5 \mathrm{~T}-16 \\
(\operatorname{lm} \times 1 \mathrm{~m})\end{array}$ & $\begin{array}{c}S T-17 \\
(\operatorname{lm} x \ln )\end{array}$ \\
\hline 0 -10en & 2 & 5 & 1 \\
\hline $10-20 \mathrm{~cm}$ & 0 & 0 & 3 \\
\hline $20 \cdot 30 \mathrm{~cm}$ & & & 0 \\
\hline \multicolumn{4}{|l|}{$30-40 \mathrm{~cm}$} \\
\hline$T \approx 1$ & 2 & 5 & 4 \\
\hline
\end{tabular}




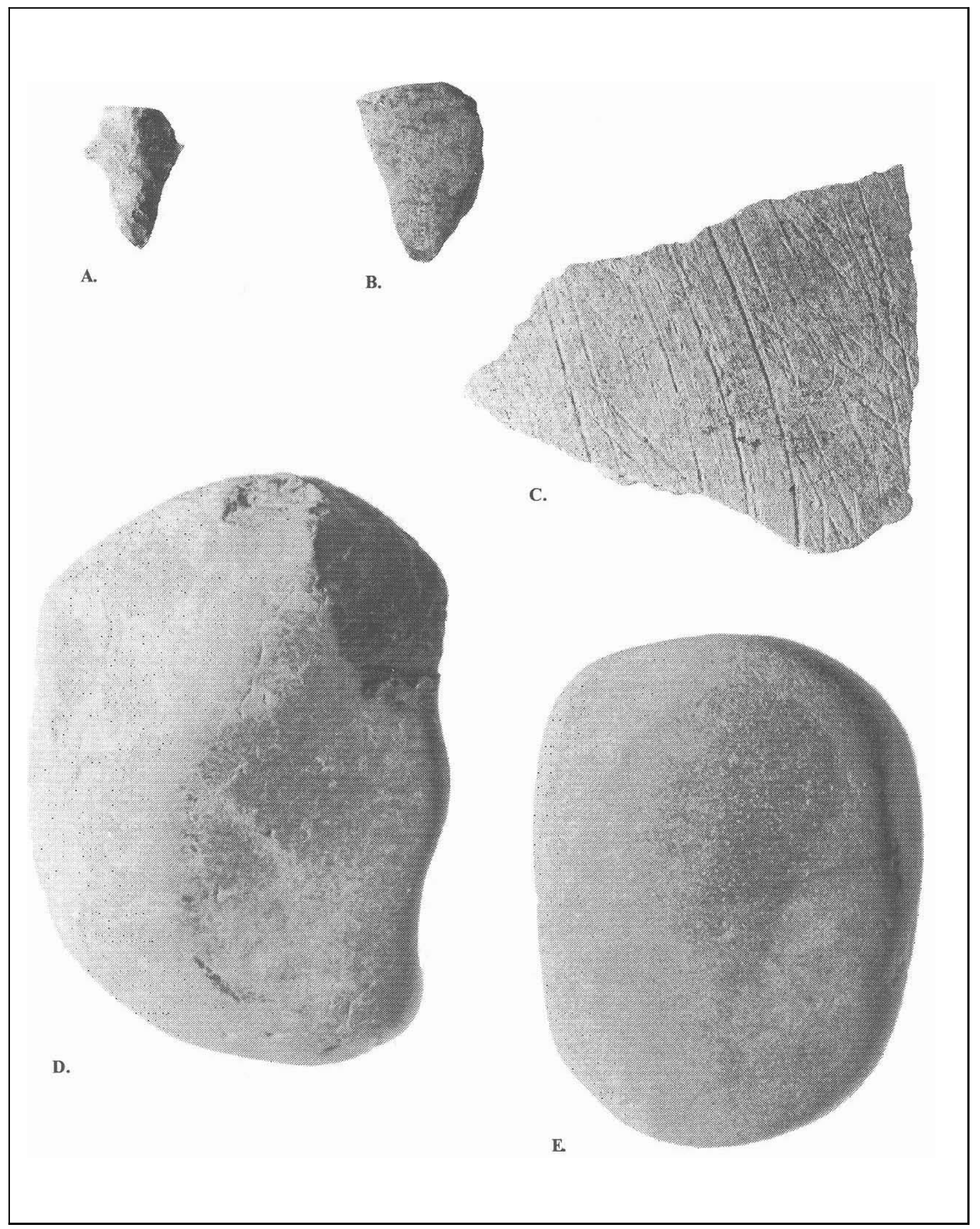

Figure 5: Selected artifacts from 41CP229. 


\section{Material TyPE}

A total of 6 major categories of raw material were identified in the present sample. In order of predominance, these are: (1) fine-grained Ogallala quartzite (Potter chert) 137, (2) flint - 30, (3) coarse-grainedquartzite - 13, (4) claystone/siltstone- 5 , (5) chalcedony/novaculite- 2 , and (6) silicified wood - 1.With 137 specimens, or 73 percent, the fine-grained Ogallala quartzite is far in the lead. Various kinds of flint, with 30 specimens ( 16 percent) is a distance second, and the only other material type in double figures. The Ogallala quartzite, some of the flint, the coarse-grained quartzite, claystone, and petrified wood are all local materials; therefore, from these figures it appears that the local knappers relied on local materials (such as Uvalde gravels) for something like 80 to 90 percent of their stone.

Like virtually every assemblage of the region, however, there is a small amount of nonlocal material such as flint, novaculite, and chalcedony fiom sources such as central Texas, Oklahoma, and Arkansas. And it is not unusual for sites of northeastern Texas to have greater percentages of exotic materials than occur in the present sample.

Only 8 of the 188 flakes and fragments from 4 1CP229 are larger than $20 \mathrm{~mm}$, so the average specimen is quite small, but not unusually so for assemblages of the region. Of the 8 specimens, 5 are $20-30 \mathrm{~mm}$ in length, and 3 are 30 $40 \mathrm{~mm}$ in length. This sample suggests that raw material of large size was not readily available (a regional phenomenon), and that tools of large size, quite expectedly, were not made in this part of the site (and probably not in any other).

\section{Diagnostic Artifacts, Biface Fragments, AND OTHER TOOLS}

A total of 11 artifacts that can be classified as tools was recovered from 41CP229 (Table 3), including several pieces broken in manufacture. Of this small sample only three specimens, one dart point and two potsherds, are more or less diagnostic of particulartime periods. The dart point is of the ubiquitous Gary type fiom the Late Archaic and Early Ceramic periods. The sherds cannot be identified as to type, but one may be from the early half of the Caddoan era, while the other is probably from the Middle or Late Caddoan Period.

The small fragmentary Gary dart point (Fig. 5, A) is 25 $\mathrm{mm}$ in length, retaining the stem, shoulders, and a small portion of the blade. At the shoulders, it is $17 \mathrm{~mm}$ wide and $6 \mathrm{~mm}$ thick. It is made of brownish red Ogallala quartzite.

Perhaps the older of the two sherds is a small, undecoratedrim fragment (Fig. 5, B). The rim is everted, rounded, and $4 \mathrm{~mm}$ in thickness; maximum thickness of the sherd is $5 \mathrm{~mm}$. The sherd's surfaces are light yellowish brown, with the exterior having a highly worn appearance while the polished interior is better preserved. The paste is dark gray and contains small amounts of bone and grog.

The second specimen is a large body sherd of brushed ware (Fig. 5, C). Its exterior and core are yellowish brown, while the interior is medium brown. The brushing was applied fiom two directions and overlaps in two areas. Grog is the tempering agent of this well-preserved sherd.

\section{Other Chipped Stone Artifacts}

Among the chipped stone sample, other tools or worked objects amount to four biface fragments and one modified flake fragment. Only one of the biface fragments is from a completed tool; it is the distal portion of a dart point. All of these specimensare made of Ogallala quartzite. The possible flake tool is the distal section (17 $\mathrm{mm}$ long) of a thin Ogallala quartzite flake. It has continuous use damage, in the form of nicking, along two adjoining edges. The edges are rounded and smoothed.

\section{Ground Stone}

Other tools from the site are ground stone, including a pitted mano, a possible mano (little used), an anvil/metate, a hammerstone, and a pitted stone (Table 4). The two manos came from the terrace margin, one from GT $1(70 \mathrm{~cm}$ deep) and the other fiom GT 2. The pitted stone is from GT 19 in the central part of the site, while the anvil/metate and hammerstone are fiom GT 28 along the ridgetop at the site's northern end.

The pitted mano (Fig. 5, E), made of quartzite, has an oblong shape and dimensions of $85 \mathrm{~mm}$ long, $65 \mathrm{~mm}$ wide, and $44 \mathrm{~mm}$ thick; its weight is $399 \mathrm{gm}$. One face has a shallow, broad depression, or pit, while the other face is generally convex but in the center there is a slight depression that might be an incipient pit. Different parts of this stone's edges have battering or smoothing from other kinds of use.

The other stone that is a possible mano is also a quartzite cobble, of an irregular to oblong shape, being 111 $\mathrm{mm}$ in length, $81 \mathrm{~mm}$ in width, and $49 \mathrm{~m} \mathrm{~m}$ in thickness; its weight is $572 \mathrm{gm}$. It has a turtleback shape, with minor smoothing on the flatter but still convex surface. This stone was not used enough to completely smooth the used surface, which retains shallow pitting and unevenness of the original surface.

Perhaps the most significant artifacts from the tested portion of 41CP229 are the two stones found together in GT 28. The larger of the two is a block of ferruginous 
sandstone that has minor smoothing on a mildly concave surface, apparently the wear fiom use as a metate and/or anvil stone. Its dimensions are: L- $170 \mathrm{~mm}$; W- $120 \mathrm{~mm}$; T$90 \mathrm{~mm}$; its weight is $3397 \mathrm{gm}$.

The stone found with the metate/anvil is a finegrained quartzite cobble of generally oblong to irregular shape (Fig. 5, D), with dimensions of $100 \mathrm{~mm}$ length, $74 \mathrm{~mm}$ width, and $45 \mathrm{~mm}$ thickness; its weight is $442 \mathrm{gm}$. It has extreme battering and some spalling fiom the thicker, wider end that was used most. A small, rounded point at the opposite end has light battering from minimal use. Overall, this damage is consistent with use as a hammerstone in flintknapping, the stone having the toughness of certain quartzites that is ideal for that purpose.

The fact that these two stones were found side-byside (20 cm deep) suggests that they were cached, and possibly used in tandem. If so, this would be a unusual find of both kinds of stones needed for hammer/anvil (previously called bipolar) reduction of siliceous materials, which is known to have been practiced in the region.
However, the wear on the anvil stone is not consistent with wear expected fiom such rough useage. The wear is light and discontinuous smoothing with no signs of pitting or scarring fiom heavy impact.

The pitted stone is a large, rough block of ferruginous sandstone. A fairly soft, reddish brown sandstone, this specimen is $133 \mathrm{~mm}$ long, $115 \mathrm{~mm}$ wide, and $73 \mathrm{~mm}$ thick. The flatter of its two faces has some natural pitting, but some small pits are the result of use. There are three of the latter, which are roughly circular, $15-20 \mathrm{~mm}$ in diameter, and about 7 or $8 \mathrm{~mm}$ deep. The surface of these pits is not smooth. A larger pitted area appears to be mostly natural, but might have been used minimally.

The reverse face of the pitted stone is very irregular, but there is a concave area through the central portion that is smooth from use as a grinding stone. The wear overlaps over one edge which is rounded, and, on the other end, over both edges created by a comer of the stone. This wear is consistent with use as a metate, although the use area, approximately $70 \times 120 \mathrm{~mm}$, is comparativelysmall.

Table 3: Distribution of tools from shovel tests at $\mathbf{4 1 C P 2 2 9}$

\begin{tabular}{|c|c|c|c|c|}
\hline DETH & ST-1 & ST-4 & ST+6 & Sr- \\
\hline $0-10 \mathrm{~cm}$ & & & & \\
\hline $10-20 \mathrm{~cm}$ & & Gary Point & & \\
\hline $20-30 \mathrm{~cm}$ & Sherd & Flake Tool & & \\
\hline $30-40 \mathrm{~cm}$ & & Biface Frag. & & Biface \\
\hline $40.50 \mathrm{~cm}$ & & & & \\
\hline $50-60 \mathrm{~cm}$ & & & & \\
\hline $60-70 \mathrm{~cm}$ & & & 2 giface Frags. & \\
\hline
\end{tabular}

Table 4: Artifact distribution in Gradall trenches at 41 CP229

\begin{tabular}{|c|c|c|c|c|c|c|}
\hline DEPTEI & GT-1 & $\mathrm{kt}-2$ & $6 r 3$ & $69-17$ & 67.19 & $61-28$ \\
\hline Indetcrmined & & & & Pos Sherd & Pitted Srone & \\
\hline \multicolumn{7}{|l|}{$0.10 \mathrm{~cm}$} \\
\hline 10. $20 \mathrm{~cm}$ & & Mano & & & & $\begin{array}{c}\text { Metats } \\
\text { Hammerstone }\end{array}$ \\
\hline $20.30 \mathrm{~cm}$ & & & 2 Hlakes & & & \\
\hline \multicolumn{7}{|l|}{$3040 \mathrm{~cm}$} \\
\hline $40-50 \mathrm{~cm}$ & Mamo & & & & & \\
\hline \multicolumn{7}{|l|}{$50 \cdot 60 \mathrm{~cm}$} \\
\hline $60.70 \mathrm{~cm}$ & Plake & & & & & \\
\hline
\end{tabular}




\section{EXCAVATIONS AT 41CP228}

The assessment of site 41CP228 appears to have been done somewhat beyond the site's margins. Due to the small size of the area, this work consisted of only three Gradall trenches and one shovel test (Fig. 6). These excavations (Table 5) were at the foot of the low hill upon which the site lies, and in the same area where previous negative shovel tests had been dug.

No cultural material was observed in the excavations or backdirt, but the surface could not be checked very well because of a thick growth of tall weeds and grass. There did occur in GT 3 a lens of sandy matrix containing abundant charcoal and a partially burned stump, but there were no artifacts. This may have been an area where a large amount of brush was burned, perhaps in the earlier part of this century. Whatever the case, the charcoal-rich lens had been covered by 30 to $40 \mathrm{~cm}$ of colluvial slope wash. The small hill had been in cultivation continuously for many years until recently, and much sand and sandstone pebbles had washed from it.

Table 5: Dimensions of Gradall trenches and test pit.

\begin{tabular}{|c|c|c|c|c|}
\hline \multicolumn{9}{|c|}{ SITE $\# 1$ CP228 } \\
\hline PIT & LENGTH & WIDTH & DEPTH & REMARKS \\
\hline GI & $6.7 \mathrm{~m}$ & $3.7 \mathrm{~m}$ & $0.9 \mathrm{~m}$ & \\
\hline $\mathrm{G} 2$ & $4.6 \mathrm{~m}$ & $1.8 \mathrm{~m}$ & $0.6 \mathrm{~m}$ & \\
\hline $\mathrm{G} 3$ & $3.7 \mathrm{~m}$ & $1.8 \mathrm{~m}$ & $1.1 \mathrm{~m}$ & \\
\hline S1 & $0.7 \mathrm{~m}$ & $0.7 \mathrm{~m}$ & $0.9 \mathrm{~m}$ & \\
\hline & & & & \\
\hline & & & & \\
\hline
\end{tabular}




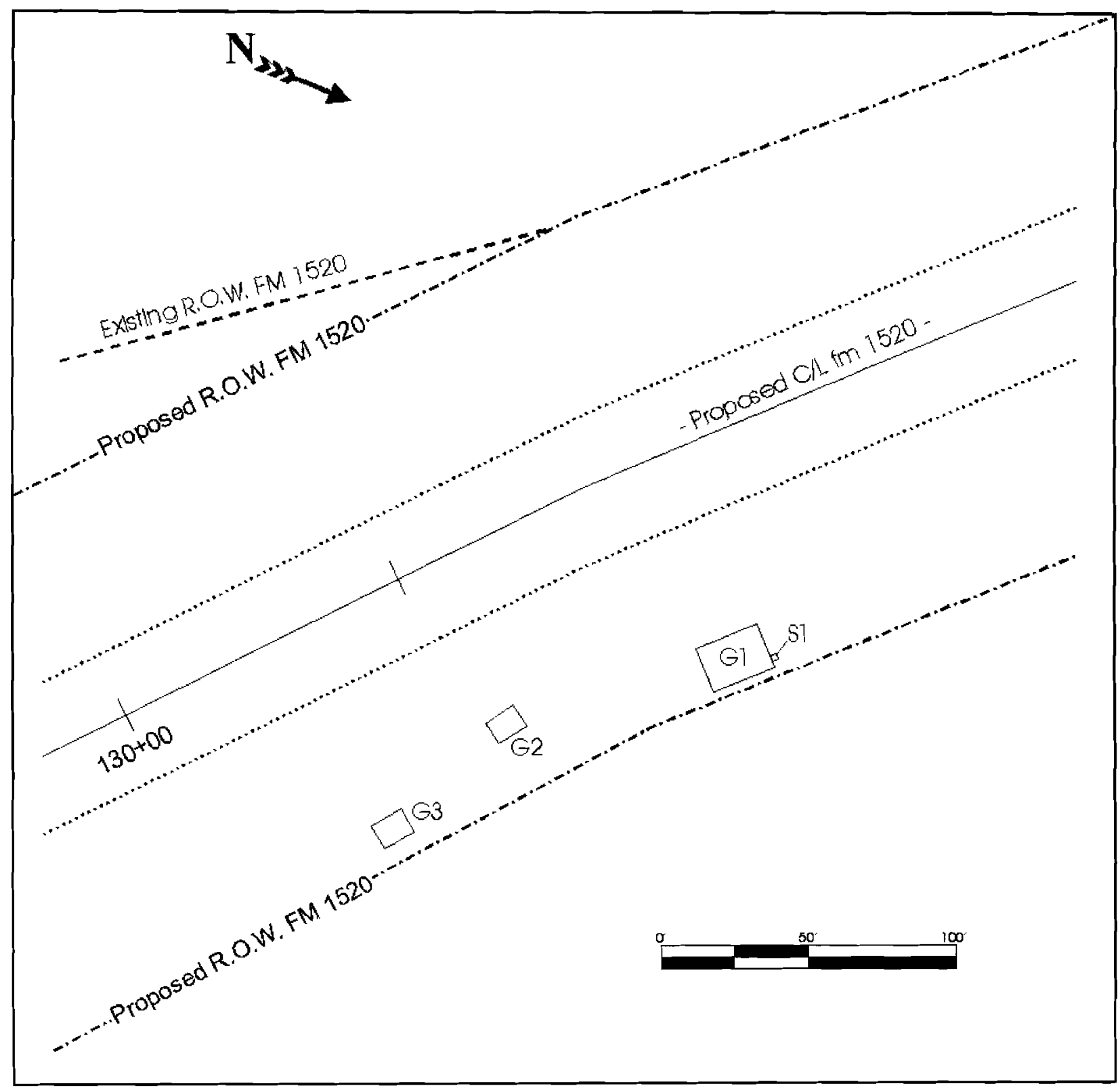

Figure 6: Location of Gradall trenches and shovel tests at 41CP229. 


\section{Assessment ANd Recommendations}

Site 41CP229is a large area of prehistoric activity, only a portion $(160 \mathrm{X} 800 \mathrm{ft}$. strip) of which occurs within the proposed right-of-way. According to local informants, the most productive part (in terms of collectable artifacts) lies to the east of the project. This area lies nearer to the confluence of Walkers Creek and its tributary to the north, which runs beside 41CP228. Therefore, it would be reasonable to expect a more abundant artifact assemblage (among other cultural materials) in the described area.

The part of the site within the proposed right-of-way, which was probed with a goodly number of excavations, was productive neither in terms of artifacts nor features. Only one of several anomalies found is thought to possibly be a prehistoric feature, and it apparently is an isolated find lacking meaningful context. No artifacts or other clues were found which could immediately place it in time. It did contain charcoal, but, without context, radiocarbon dating would be a useless exercise.

After a close look at the site, it is determined that the part of $41 \mathrm{CP} 229$ within the proposed right-of-way is insignificant and does not merit further work.

The area of the proposed project that runs near site $41 \mathrm{CP} 228$ was much smaller and much easier to access. If the western margin of this site does extend into the project area, it is so sparsely represented that no cultural material has yet been found. From viewing the condition of site 41CP228, it is unlikely that whatever part of it lies within the old field retains any significance, and there is certainly no evidence that anything of significance lies within the projectarea.

The proposed project, then, appears to only skirt site 41CP228, contains no significantcultural material, and does not merit further work. 


\section{References Cited}

Blair,W.F.

1950 The Biotic Provinces of Texas. Texas Journal of Science 2: 93-117

Bureau of Economic Geology

1966 Geologic Atlas of Texas; Texarkana Sheet.

Carr;J.T.

1967 The Climate and Physiography of Texas. Report 53; Texas Water Development Board, Austin, Texas.

Perttula, Timothy K.

1996 Personal communication with the author in October 1996.

Sellards, E. H., W. S. Adkins, and F. B. Plummer 1932 The Geology of Texas. Bulletin 3232. The University of Texas at Austin.
Story, Dee Ann

1981 An Overview of the Archaeology of East Texas. Plains Anthropologist 26: 139-156.

United States Department of Agriculture Soil

Conservation Service n.d. Soil Survey of Camp County, Texas.

Young, Wayne

1981 Test Excavations at the Tankersley Creek Site, Titus County, Texas. SDHPTReport No. 22, Austin, Texas. 